Full-text Available Online at https://www.ajol.info/index.php/jasem http://ww.bioline.org.br/ja
J. Appl. Sci. Environ. Manage.

Vol. 24 (5) 857-862 May 2020

\title{
Effects of Seasonal Characteristics of Kolo Creek Flooding on Farm-Plot Sizes in Central Niger Delta, Nigeria
}

\author{
${ }^{1}$ ELI, HD; *2.BARIWENI, PA
}

\author{
${ }^{1}$ Department of Geography \& Environmental Management, Niger Delta University, Wilberforce Island, Bayelsa State, Nigeria \\ ${ }^{* 2}$ Department of Marine Environment \& Pollution Control, Nigeria Maritime University, Okerenkoko, Delta State \\ *Corresponding AuthorEmail:pbariweni@yahoo.com; revelihorsfall@gmail.com
}

\begin{abstract}
Perennial flooding is a known environmental hazard in many parts of the Niger Delta. Concern about flooding increases when places of importance to man, such as farmlands and settlements, and food supply systems are affected. This study assessed the effect of Seasonal Characteristics of Kolo Creek flooding on farm-plot sizes and crop production during the flood and non - flood seasons. A direct contact survey methodology was employed to measure farm-plot sizes and their extent of inundation during flood and non - flood seasons, and 400 randomly selected farmers along the Kolo Creek, Central Niger Delta were interviewed with a semi - structured questionnaire. Results from the study showed a mean farm-plot size of $0.51 \pm 0.00$ (Ha) during the non-flood period and $0.10 \pm 0.00 \mathrm{(Ha}$ ) during the flood period. The results obtained from the study also indicated that only $20.93 \%$ of the farm-plots available during the non - flood period was available for farming during the flood period; more than half of the farmlands of about $88.50 \%$ of the farmers was seasonally inundated by flood and only $1.75 \%$ of the farmers had less than half of the farmlands under the floodwaters. Although farmers adapted by owning many - but - small farm-plots, they cultivated only a few varieties of crops, most of which were not flood tolerant. The study concluded that Kolo Creek flooding greatly reduced farm-plot sizes and therefore recommended the planting of more flood-tolerant crops to maximize use of land and improve crop productivity in the area.
\end{abstract}

DOI: https://dx.doi.org/10.4314/jasem.v24i5.20

Copyright: Copyright (C) 2020 Eli and Bariweni. This is an open access article distributed under the Creative Commons Attribution License (CCL), which permits unrestricted use, distribution, and reproduction in any medium, provided the original work is properly cited.

Dates: Received: 13 March 2020; Revised: 30 April 2020; Accepted: 21 May 2020

Keywords: Seasonal flooding, farm-plot sizes, Kolo Creek, Niger Delta

Rivers and their characteristics have a close relationship with both the natural and human activities in the vicinity within which they flow. Until a specific river is studied, its peculiarity in basic characteristics such as flow patterns, velocity, volume, width, length, depth, turbidity, flooding extent, etc can hardly be fully understood. Flooding is a situation whereby, a land that is not normally submerged by water becomes submerged. It occurs when ponds, lakes, riverbeds, soil and vegetation cannot absorb all the water, or water runs off the land in quantities that cannot be carried within the channels or retained in natural ponds, lakes and manmade reservoirs (Bariweni et al., 2012). The causes of flooding include excessive rainfall, or snow melt within a catchment area, blockages of water courses and flood channels, storms and tidal influences, etc. The type of flood notwithstanding (be it river flooding, flash flooding, flood pondage, urban flooding, coastal flooding, or tsunamis), the expectation at its occurrence is something destructive. It is as a result of this that flooding is generally accepted as an environmental hazard (Eli, 2012; Singh, 2014). The phenomenon of flooding is of concern when places of importance to man, such as farmlands, settlements, and food supply systems are affected. Following historical trends, floods have wrought great calamities on humans, destroying settlements, properties, and farmlands and inflicting great sufferings on the people concerned. The Hwang Ho River in China is nick- named "the Chinese sorrow" because of the havoc it has wrecked on the people through flooding (Eze and Abua, 2003). Deductions from Steel and Steel (1981), Ashton Jones (1998) and Iloeje (2004) indicated that African rivers flood seasonally and do affect the lives of the surrounding people and their environment. Once flood water comes in contact with farmlands, it leads to loss of crops, reduction of cultivable lands and increase in food prices among others in any local economy ( $\mathrm{Mba}$, 1996).

However, river flooding is not all about disasters, but can also be beneficial and instrumental to physical (land) and agricultural development, as well as human civilization (Bariweni, et al., 2012; Eli, 2012). The records about Egyptian civilization and the Mesopotamian regional civilization were induced by floods of the Nile, Tigris, and Euphrates Rivers,

*Corresponding Author Email: pbariweni@yahoo.com; revelihorsfall@gmail.com 
respectively (Robinson, 1979; Ashton - Jones, 1998). This notwithstanding, the magnitude of disasters often associated with flood has increased global concern for flooding. Therefore, the occurrence of floods in the Niger Delta region of Nigeria in general, and the Kolo Creek in particular, call for concern from various quarters, both in Nigeria and outside.

Many studies have been carried out on flood recession farming (Nederveen, n.d; Saarnak, 2003; Sidibe et al., 2016); and flood impact on farmlands (Das, 2012; Wilson et al., 2012). However, there is no evidence of studies assessing the impact of floods on farm - plot sizes. Although, in 1961, a study on waters in the Niger Delta was carried out by Netherland Engineering Consultants (NEDECO), but very little was said about Kolo Creek. Also, in 1980 the services of flood experts from the Democratic Republic of Korea were imported to study the flood problem of Forcados and Nun Rivers catchment areas, yet, virtually, nothing serious was done about the Kolo Creek. Therefore, the objective of this study is to assess the seasonal characteristics of Kolo Creek and provide the non - existent data on the impact of flooding on farm - plot sizes in the Kolo Creek basin.

\section{MATERIALS AND METHODS}

The Study Area: Kolo Creek is located in the central Niger Delta (Alagoa, 1999). It extends between Latitude $4^{0} 23^{\prime}$ and $4^{0} 36^{\prime} \mathrm{N}$, and Longitude $6^{0} 14^{\prime}$ and $6^{0} 16^{\prime} \mathrm{E}$. It is the sixth longest river after Rivers Orashi, Ase, Forcados and Nun and Taylor Creek in the Forcados and Nun catchment areas of Niger Delta.

Kolo Creek takes its source from the Orashi River through a divergence at Okarki - Town in Rivers State as a fresh water stream, flowing North-South and terminating at Ekole Creek near Dorgu - Ama, Okoroma- Tereke in Nembe Local Government Area of Bayelsa State in a Mangrove environment. Much of the Kolo Creek (about 75 percent) lies in Ogbia Local Government Area of Bayelsa State (i.e from Otuegwe to Oloibiri). Apart from Orashi River as a major source, Kolo Creek also gets its source of water supply from many minor water courses as tributaries along its channel. The tributaries include Abonu-Creek between Imiringi and Otuegila, Otuoke Creek and Iyi AKoloman Creek (NDBDA, 1980; Okonny et al., 1999; Eli, 2012) (Figure 1).

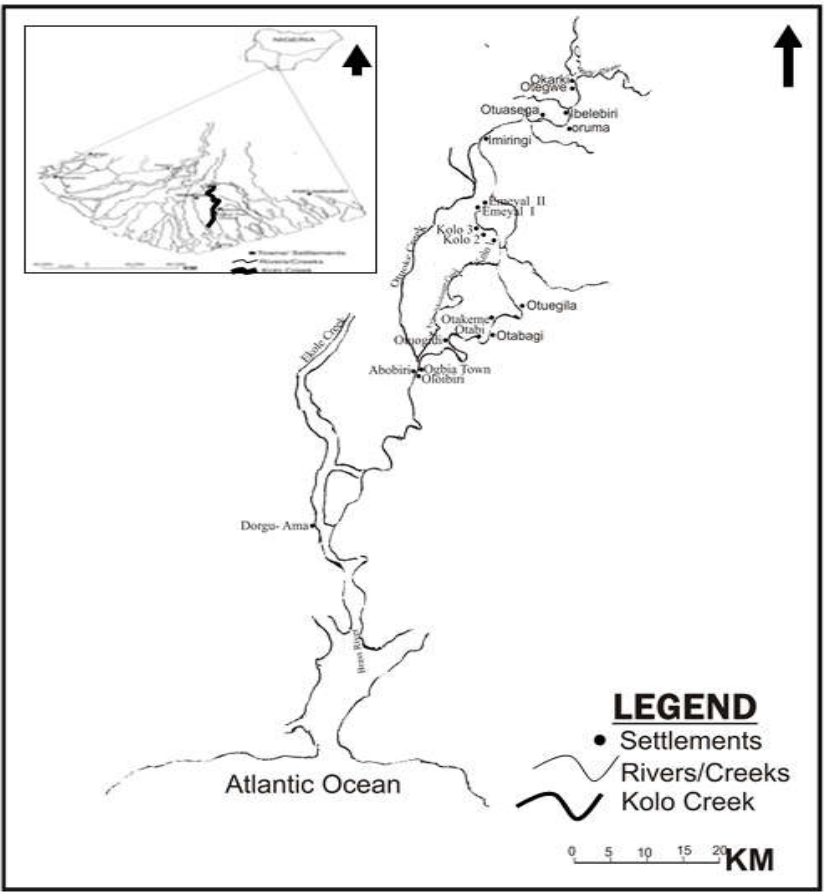

Fig 1. Kolo Greek and its tributaries in Bayelsa State, Nigeria: Source: Cartography Unit, Niger Delta University, Bayelsa State

The Kolo Creek basin lies within the equatorial climatic zone and is therefore hot and very humid, with Mean Annual Rainfall (MAR) of about 3,000mm. The dry season lasts from November to March, and the wet season from April to October. It is important to note that the driest months are December, January and February, while the rainiest months are June, July and September (Joint Industry Committee (JIC), 2001; Eli, 2012). With a relief of about 18 metres above sea level at its highest point, Kolo Creek basin has a topography 
of relatively flat plain. Its alluvial soil type, which is generally sandy - clay (Eli, 2012), encourages subsistent agriculture. The presence of two important oil fields (namely Oloibiri oil field and Kolo Creek oil field) notwithstanding, the area is largely a rural landscape.

Field Method: The study utilized semi-structured questionnaires and Personal observation on the physical environment. A total of 400 questionnaires were administered to farmers in order to determine the impact of flooding on farm - plot sizes in the Kolo Creek Basin. Direct measurements of farm - plot sizes flood-depth were also carried out during the flood and non - flood period to determine the extent of flood coverage on farm-plots using calibrated ranging poles and measuring tape. Ten farm-plots each were assessed from 19 communities (Okarki, Otuegwe, Ibelebiri, Oruma, Otuasega, Imiringi, Emeyal II, Emeyal I, Kolo III, II, I, Otuegila, Otakeme, Otabagi, Otabi, Otuogidi, Ogbia-Town, Abobiri and Oloibiri) to determine the level of inundation of the farmlands by annual flooding in the Kolo Creek basin area. Sizes of the ten farm-plots were measured and averaged to obtain the mean size for each community. All direct contact survey was carried out for three years - 2015, 2016 and 2017 to assess the seasonal characteristics of floods in the Kolo Creek basin and its impact on farm - plot sizes.

Data Analysis: Data obtained from the study were analyzed with simple percentages, means and standard deviation.

\section{RESULTS AND DISCUSSIONS}

Information obtained from direct field observation showed that the Kolo Creek has a tidal and non-tidal flow pattern. The seasonality of these flow patterns is influenced by the flood regime. During the non - flood period, the Kolo Creek has a non-tidal flow (NorthSouth), from its source at Okarki to after Kolo, while during the flood season, it exhibits a tidal flow pattern from around Otuegila to its mouth at Dorgu-Ama (where the flow pattern is both north-south and southnorth). However, at the peak of the flood, the tidal flow withdraws to the neighbourhood of Otuogidi to its mouth. This finding is in line with those of Tagaka et al. (2013), who observed tidal damping of flood water during the rainy season. Direct observation of the study area from source (Okarki) to mouth (DorguAma) also revealed that Kolo Creek as a geomorphic feature, floods once a year, with peak flood period in September and October. By November, the floodwater recedes. Further observation and measurements showed that farms along the Kolo Creek begin to get inundated as early as May - June when heavy rain water collects in depressed points of the Kolo Creek flood plain as flood pondages. These get dried during the August- Break before getting inundated again in September when the actual flooding (induced by the Niger-Benue systems) of the Kolo Creek takes effect. We refer to this pattern of flooding from May-June before drying up in August break as 'false flooding of Kolo Creek'.

\begin{tabular}{|c|c|c|c|c|c|c|c|c|c|}
\hline \multirow[t]{2}{*}{ S/No } & \multirow[t]{2}{*}{$\begin{array}{l}\text { Name of farm } \\
\text { land }\end{array}$} & \multicolumn{2}{|c|}{$\begin{array}{l}\text { Farm-size in } 2009 \\
\text { (Ha) }\end{array}$} & \multicolumn{2}{|c|}{$\begin{array}{l}\text { Farm-size in } 2010 \\
\text { (Ha) }\end{array}$} & \multicolumn{2}{|c|}{$\begin{array}{l}\text { Farm-size in } 2011 \\
(\mathrm{Ha})\end{array}$} & \multicolumn{2}{|c|}{ Mean farm-size (Ha) } \\
\hline & & $\begin{array}{l}\text { flood } \\
\text { period }\end{array}$ & $\begin{array}{l}\text { Non- } \\
\text { flood } \\
\text { period }\end{array}$ & $\begin{array}{l}\text { flood } \\
\text { period }\end{array}$ & $\begin{array}{l}\text { Non- } \\
\text { flood } \\
\text { period }\end{array}$ & $\begin{array}{l}\text { Flood } \\
\text { period }\end{array}$ & $\begin{array}{l}\text { Non- } \\
\text { flood } \\
\text { period }\end{array}$ & Flood period & $\begin{array}{l}\text { Non-flood } \\
\text { period }\end{array}$ \\
\hline 1. & Okarki & 0.22 & 0.89 & 0.21 & 0.9 & 0.2 & 0.91 & $0.21 \pm 0.01$ & $0.90 \pm 0.01$ \\
\hline 2. & Otuegwe & 0.21 & 0.87 & 0.19 & 0.9 & 0.2 & 0.9 & $0.20 \pm 0.01$ & $0.89 \pm 0.02$ \\
\hline 3. & Ibelebiri & 0.18 & 0.82 & 0.2 & 0.8 & 0.21 & 0.8 & $0.20 \pm 0.02$ & 0.810 .01 \\
\hline 4. & Oruma(Yibama) & 0.095 & 0.82 & 0.12 & 0.8 & 0.1 & 0.8 & $0.11 \pm 0.01$ & $0.81 \pm 0.01$ \\
\hline 5. & Otuasega & 0.09 & 0.69 & 0.09 & 0.7 & 0.091 & 0.7 & $0.09 \pm 0.00$ & $0.70 \pm 0.01$ \\
\hline 6. & Imiringi & 0.21 & 0.4 & 0.2 & 0.4 & 0.21 & 0.4 & $0.21 \pm 0.01$ & $0.40 \pm 0.00$ \\
\hline 7. & Emeyal II & 0.08 & 0.31 & 0.081 & 0.3 & 0.08 & 0.3 & $0.08 \pm 0.00$ & $0.30 \pm 0.01$ \\
\hline 8. & Emeyal I & 0.1 & 0.4 & 0.1 & 0.4 & 0.11 & 0.4 & $0.10 \pm 0.01$ & $0.40 \pm 0.00$ \\
\hline 9. & Kolo III & 0.071 & 0.39 & 0.07 & 0.41 & 0.069 & 0.4 & $0.07 \pm 0.00$ & $0.40 \pm 0.01$ \\
\hline 10. & Kolo II & 0.052 & 0.4 & 0.05 & 0.4 & 0.05 & 0.4 & $0.05 \pm 0.00$ & $0.40 \pm 0.00$ \\
\hline 11. & Kolo I & 0.05 & 0.3 & 0.054 & 0.3 & 0.05 & 0.3 & $0.05 \pm 0.00$ & $0.30 \pm 0.00$ \\
\hline 12. & Otuegila & 0.012 & 0.4 & 0.01 & 0.4 & 0.011 & 0.4 & $0.01 \pm 0.00$ & $0.40 \pm 0.00$ \\
\hline 13. & Otakeme & 0.079 & 0.42 & 0.08 & 0.3 & 0.082 & 0.4 & $0.08 \pm 0.00$ & $0.37 \pm 0.06$ \\
\hline 14. & Otabagi & 0.09 & 0.49 & 0.089 & 0.5 & 0.09 & 0.5 & $0.09 \pm 0.00$ & $0.50 \pm 0.01$ \\
\hline 15. & Otabi & 0.081 & 0.5 & 0.08 & 0.53 & 0.08 & 0.5 & $0.08 \pm 0.00$ & $0.51 \pm 0.02$ \\
\hline 16. & Otuogidi & 0.09 & 0.3 & 0.091 & 0.3 & 0.09 & 0.3 & $0.09 \pm 0.00$ & $0.30 \pm 0.00$ \\
\hline 17. & Ogbia-Town & 0.089 & 0.41 & 0.09 & 0.4 & 0.09 & 0.4 & $0.09 \pm 0.00$ & $0.40 \pm 0.01$ \\
\hline 18. & Abobiri & 0.08 & 0.4 & 0.08 & 0.4 & 0.081 & 0.4 & $0.08 \pm 0.00$ & $0.40 \pm 0.00$ \\
\hline 19. & Oloibiri & 0.11 & 0.39 & 0.1 & 0.4 & 0.1 & 0.4 & $0.10 \pm 0.01$ & $0.40 \pm 0.01$ \\
\hline \multicolumn{2}{|c|}{ Average Farm Size } & 0.105 & 0.51 & 0.104 & 0.51 & 0.105 & 0.51 & $0.10 \pm 0.00$ & $0.51 \pm 0.00$ \\
\hline
\end{tabular}


Results from the study on mean farm-plot sizes in the Kolo Creek basin during the flood and non-flood periods are presented in Table 1 , while Table 2 presents the percentage farm-plot sizes during the peak flood period and the extent of farm-plots inundation along the Kolo Creek basin. Results from the study showed a mean farm-plot size of $0.51 \pm 0.00$ (Ha) during the non-flood period and a mean of $0.10 \pm 0.00$ (Ha) during the flood period (Table 1). A cursory look at the results indicated that only about $20.93 \%$ of the farm-plots available during the non - flood period was available for farming during the flood period. This implied that about $79.07 \%$ of the farm-plots were inundated during the peak flood period and therefore lost to farming activities (Table 2). The observed results are similar to that of Enete et al. (2013). This means further that, all benefits from the farms along the creek are seasonally influenced by the flooding regime and associated behaviour of the stream. A further probe on the extent of flooding in the Kolo Creek Basin through semi - structure interview of 400 farmers in the area further confirms the situation. Results from the interview showed that the farmlands of about $4.50 \%$ of the farmers in the study area were completely flooded; one half of the farmlands of about $5.25 \%$ of the farmers were covered by the floods; more than half of the farmlands of about $88.50 \%$ of the farmers was seasonally inundated by flood and only $1.75 \%$ of the farmers had less than half of the farmlands under the floodwaters. The implication of the observed seasonality characteristics of the Kolo Creek is the small size of farm - plots in the area and the consequent low farm output as well as low income for the farmers in the area.

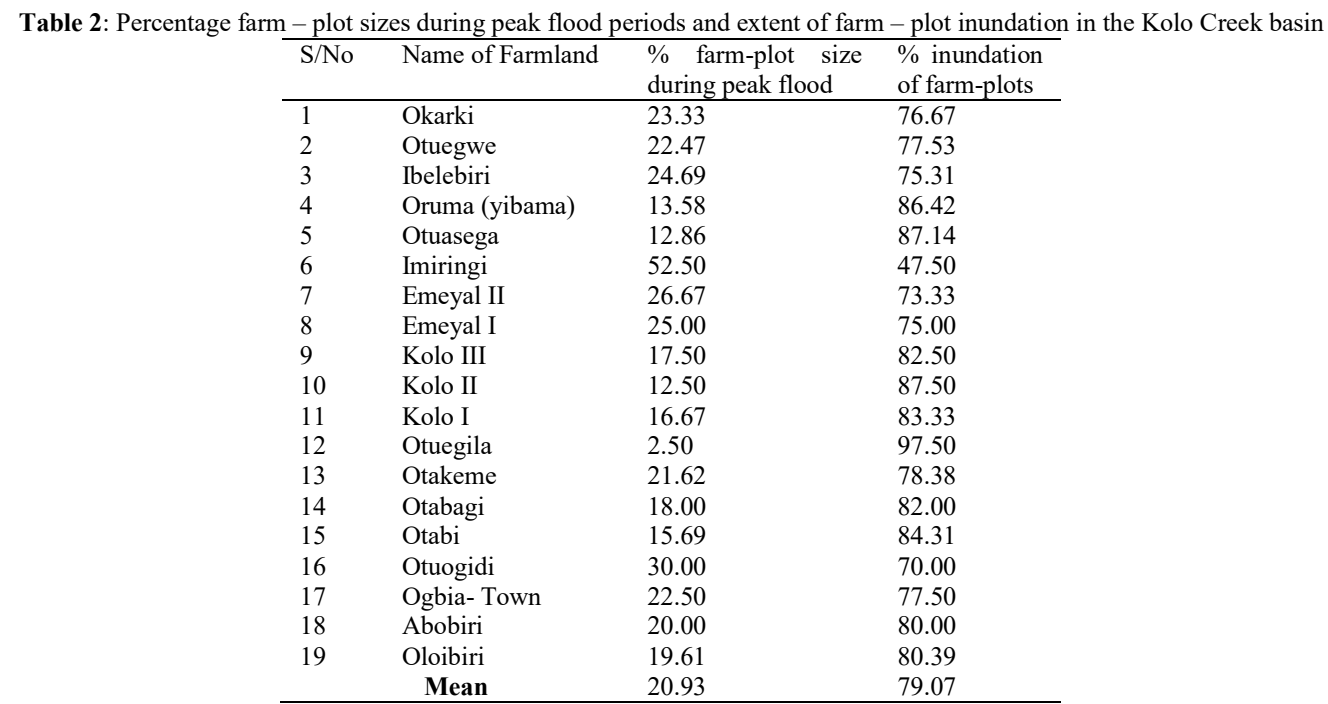

Table 3: Number of Farm plots owned by individual farmers along the Kolo Creek

\begin{tabular}{llll}
\hline S/No & Number Of Farm Plots & Frequency & $(\%)$ \\
\hline 1 & 1 plot & - & 0 \\
2 & 2 plots & 1 & 0.25 \\
3 & 3 plots & 18 & 4.5 \\
4 & 4 plots & 19 & 4.75 \\
5 & 5 plots & 86 & 21.5 \\
6 & 6 plots & 68 & 17 \\
7 & 7 plots & 24 & 6 \\
8 & 8 plots & 68 & 17 \\
9 & 9 plots & 116 & 29 \\
& TOTAL & 400 & 100 \\
\hline
\end{tabular}

In order to survive the annual loss of farm produce and increase their harvest as well as income, farmers in the area have adopted a number of strategies including early farming and the cultivation of several small farm - plots. Results from the study also revealed that about $90 \%$ of the farmers in the area possessed at least five plots and more (Table 3 ) to boost their productivity and enhance their personal income. In view of the seasonal occurrence of flooding in the area, it was expected that farmers would cultivate flood resistant crops to survive the seasonal adversity. However, this was not the case as farmers in the area cultivated only a few varieties of crops, most common of which are not flood tolerant. Table 4 presents the major crops grown along the Kolo Creek. 
Table 4: Major Crops grown along the Kolo Creek

\begin{tabular}{llll}
\hline S/N & Type Of Crop & Frequency & $\mathbf{( \% )}$ \\
\hline 1 & Cassava (Manihot esculentu) & 400 & 100 \\
2 & Plantain (Musa paradisiacal) & 400 & 100 \\
3 & Banana (Musa accuminata, Musa balbisiana) & 400 & 100 \\
4 & Cocoyam (Colocasia esculenta) & 400 & 100 \\
5 & Vegetables & 6 & 1.5 \\
6 & Sugar Canes (Saccharum officinarum) & 5 & 1.25 \\
7 & Water yam (Dioscorea spp) & - & 0 \\
8 & Rice (Oryza sativa) & - & 0 \\
\hline
\end{tabular}

From the study, it was observed that rice and water yam which were more flood tolerant were not cultivated at all. This was found not to be in sync with recommended sustainable practice of cultivating flood tolerant crop cultivars (Verhoeven and Setter, 2009).

Conclusion: It may be concluded from this study that annual seasonal flooding greatly influenced farming activities along the Kolo Creek basin through massive annual reduction of available farm - plot sizes, which consequently lead to low output and low earnings. Farmers in the area did not adapt to the environment by cultivating flood tolerant crops. It is recommended that farmers in the area adopt sustainable farming practices through cultivation of flood tolerant crops, such as swamp rice, sugarcane, etc. side by side with the regular native crops. This will help maximize use of flooded landmass and increase their productivity as well as reduce poverty in the area.

\section{REFERENCES}

Adetunji, AM (2006). The Nigerian Environment. National Open University of Nigeria, Lagos, Nigeria

Alagoa, EJ (1999). The Land and People of Bayelsa State. Central Niger Delta. Onyoma Research Publications, Port Harcourt, Nigeria

Allison - Oguru, EA; Zuofa, D; Berepubo, N.A (1999). Agriculture. In: EJ Alagoa (ed). The Land and People of Bayelsa State: Central Niger Delta Onyoma Research Publications Port-Harcout, Nigeria.

Aniah, EJ (2006). Comparative Analysis of Regional Development Strategies / Paradigms in Africa/Asia In: MO Ebong (ed) Introduction to Regional Development Planning. Calabar, Mabass Printers.

Ashton - Jones, N (1998). The Human Ecosystems of the Niger Delta. An ERA Handbook. Environmental Rights Action, Benin City, Nigeria.
Bariweni, PA; Tawari, CC; Abowei, JFN (2012). Some Environmental Effects of Flooding in the Niger Delta Region of Nigeria. International Journal of Fisheries and Aquatic Sciences 1(1): 35-46, 2012

Das, K (2012). Farm Productivity Loss due to FloodInduced Sand Deposition: A Study in Dhemaji, India Kalyan Das. Working paper. South Asian Network for Development and Environmental Economics. Retrieved 15/9/17 from www.sandeeonline.org/uploads/.../990_PUB _Working_Paper_73_Kaylan_Das.pdf

Eli; HD (2012). Analysis of flooding on Farmlands along the Kolo Creek of Bayelsa State, Nigeria. (Unpublished) PhD Thesis. University of Calabar, Calabar

Enete, AA; Obi, JN; Ozor, N; Mba, CL (2016). Socioeconomic Assessment of Flooding among Farm Households in Anambra State, Nigeria. International Journal of Climate Change Strategies and Management. ISSN: 1756-8692. Retrieved 28/3/2020 from https://www.emerald.com/insight/content/doi/10. 1108/IJCCSM-07-2014-0084/full/html

Eze, BE; Abua, MA (2003). Water Resources Management. Ushie Printers, Calabar

Ibouya, BA (1999). Comprehensive Certificate Geography. Benking Intellectual Publishers, Benin City

Iloeje, NP (2004). A New Geography of Nigeria. Learn Africa Plc Ikeja, Lagos, Nigeria

Joint Industry Committee - JIC (2001). Bonny Master Plan. Upton Ville Port Harcourt

Kaniaru, D (1998). Environmental Imperative for the African Region in the Next Decade; Strategies for Advancement: In: A. Ogbuigwe (ed) Apex Lectures on the Environmental and Development. Apex Environmental Law Centre. Port Harcourt 
Mba, HC (1996). Towards more environmental conscious development politics in $21^{\text {st }}$ Century Nigeria. Proceedings of the $27^{\text {th }}$ of the Nigerian Institute of Town Planners, Benin

NEDECO (1961). The Waters of the Niger Delta. Report on an Investigation. Netherlands Engineering consultants, The Hague

Nederceen, SC (n.d). Flood Recession Farming: An Overview and Case Study from the Upper Awash Catchment, Ethiopia. Master thesis Hydrology, code 450122, 39 ECTS. Retrieved 16/9/17 from $\mathrm{http}$ //www.spate-irrigation.org/wordpress/wpcontent/uploads/Thesis_Flood_based_farming.pd $\mathrm{f}$

Niger Delta Basin Development Authority (1980). Report on the Investigation of Possible Flood Protection measuring in the Nun and Forcados Rivers Area. Flood Protection Delegates from D.P.K Korea. NDBDA, Port Harcourt

Okonny, IP; Ayolagha, G Dickson AA (1999). Geology and soils. In: E.J Alagoa (Ed) The land and people of Bayelsa State Central Niger Delta. Port Harcourt: Onyoma Research Publications, 9 -30 .

Raven, PH; Berg, LR; Johnson, GB (1993). Environment. Sounders College Publishers, New York

Robinson, H (1979). Geography for Business Studies. Mc Donald Evans Norwich

Saarnak, NL (2003). Flood Recession Agriculture in the Senegal River Valley. Geografisk Tidsskrift Danish Journal of Geography 103(1): 99-113, 2003

Salter, CI; Hobbs, JJ; Wheeler Jr, JH; Kostbade, JT (2000). Essentials of World Regional Geography. Saunders College Publishers, New York
Sidibe, Y; Williams, TO; Kolavalli, S (2016). Flood Recession for Food Security in Northern Ghana: Literature Review on Extent, Challenges and Opportunities. International food policy research institute, working paper 42

Singh J; Moffat, D; Linden, O (1995). Deriving an Environmental Strategy of the Niger Delta. World Bank, Washington, D C.

Singh, S (2014). Environmental Geography. Pravalika Publications, Allahabad, India

Steel, RW; Steel, EM (1981). Geographies: A certificate series. Longman London

Tagaki, H; Van, TT; Thao, ND; Esteban, M (2013). Ocean Tides and the Influence of Sea - Level Rise on Floods in Urban Areas of the Mekong Delta. Journal of Flood Risk Management 8(4). Doi: 10.1111/jfr3.12094. Retrieved 28/3/2020 from

https://www.researchgate.net/publication/259552972 Ocean Tides and the Influence of SeaLevel Rise on Floods in Urban Areas of the Mekong Delta

Thornbury, WD (1969). Principles of Geomorphology. John Wiley and sons New York

Wilson, JA; Olson, SL; Callan, J (2011). Farming after the Flood. American Society of Agronomy. Retrieved 16/9/17 from https://www.soils.org/files/sciencepolicy/caucus/briefings/farming-after-flood.pdf

Verhoeven, JTA; Setter, TL (2009). Agricultural use of wetlands: Opportunities and limitations. Ann Bot, 105(1): 155 - 163. Retrieved 18/9/17 from https://www.ncbi.nlm.nih.gov/pmc/articles/PMC 2794053 